\title{
CARDIORESPIRATORY RESPONSES TO ISOKINETIC EXERCISE IN PATIENTS WITH CORONARY ARTERY DISEASE
}

\author{
RESPOSTAS CARDIORRESPIRATÓRIAS AO EXERCICIO ISOCINÉTICO EM PACIENTES COM DOENÇA \\ ARTERIAL CORONARIANA
}

Original Artigie

ARTIGO ORIGINAL

Artículo Original

\author{
RESPUESTAS CARDIORRESPIRATORIAS AL EJERCICIO ISOCINÉTICO EN PACIENTES CON ENFERMEDAD \\ ARTERIAL CORONARIA
}

\begin{abstract}
Aline Ertel Ribeiro' (iD
(Physiotherapist)

Suelen Bordin' (ID)

(Physiotherapist)

Talinara Cristine Marini' (DD

(Physiotherapist)

Vivian Carla Florianovicz' (DD (Physiotherapist)

Gilnei Lopes Pimentel ${ }^{1}$ (D)

(Physiotherapist)

José Basileu Caon Reolão' (ID

(Physician)

Thiago Gomes Heck (DD

(Physical Education Professional)

Leonardo Calegari',3 (D)

(Physiotherapist)

1. Universidade de Passo Fundo (UPF), Passo Fundo, RS, Brazil.

2. Universidade do Noroeste de

Rio Grande do Sul (UNIJUÍ), Ijuí,

RS, Brazil.

3. Faculdade Especializada na Área da Saúde do Rio Grande do Sul (FASURGS), Passo Fundo, RS, Brazil.
\end{abstract}

\section{Correspondence:}

Leonardo Calegari

Curso de Fisioterapia FASURGS.

Rua Angélica Otto, 160, Boqueirão, Passo Fundo, RS, Brazil. 99025-270. profcalega@gmail.com

\begin{abstract}
Introduction: Exercise training using an isokinetic dynamometer is an alternative for improving muscle strength in patients with coronary artery disease (CAD). Few studies have shown metabolic and cardiorespiratory responses to submaximal isokinetic exercises in patients in cardiac rehabilitation programs. Objective: To describe cardiorespiratory responses at two intensities of isokinetic exercise. Additionally, we compared the cardiorespiratory responses of isokinetic exercise with data from the incremental cardiopulmonary exercise test (CPET). Methods: Eight individuals with CAD (61.7 \pm 6.6 years) performed the following tests: 1$)$ CPET on a treadmill; 2 ) Peak torque test (five repetitions) and fatigue resistance test (20 repetitions) of knee flexion-extension at angular speeds of $120 \% \mathrm{~s}$ and $180 \% \mathrm{~s} ; 3$ ) Two sets of 20 repetitions were performed at 30-40\% (low-intensity, LI) and 50-60\% (moderate-intensity, MI) of peak torque at angular speeds of $120 \% \mathrm{~s}$ and $180 \%$, using an isokinetic dynamometer. During the exercises, the individuals were connected to an expired gases analyzer with simultaneous monitoring of the electrocardiogram trace, heart rate $(\mathrm{HR})$, oxygen consumption $\left(\mathrm{VO}_{2}\right)$, carbon dioxide production, and minute ventilation $\left(\mathrm{V}_{\mathrm{E}}\right)$. The differences $(\Delta)$ between the peak measurements during exercises and the baseline values were calculated. Results: Both $L I$ and Ml produced cardiorespiratory responses below the anaerobic threshold $\left(82.8 \pm 8.1 \%\right.$ of $\mathrm{HR}_{\max }$ and $74.4 \pm 9.6 \%$ of $\left.V \mathrm{O}_{2 \text { peak }}\right)$ compared to the CPET data $(P<0.01)$. Ml showed higher $\triangle \mathrm{HR}(9.8 \pm 5.5 \mathrm{vs} .6 .3 \pm 4.6 \mathrm{bpm} ; P=0.01), \triangle$ rate pressure product $(3015 \pm 2286 \mathrm{vs} .1957 \pm 1932 \mathrm{mmHg} \cdot b p m ; P=0.01)$, and $\Delta V_{E}\left(10.2 \pm 6.2 \mathrm{vs} .6 .9 \pm 7 \mathrm{~L} \cdot \mathrm{min}^{-1} ; P=0.03\right)$ than $\mathrm{Ll}$ at the angular velocity of $180^{\circ} \mathrm{s}$. Conclusion: These results suggest that this isokinetic exercise protocol may be used as a strategy for cardiac rehabilitation programs in patients with CAD. Level of evidence IV; Case series.
\end{abstract}

Keywords: Muscle strength dynamometer; Oxygen consumption; Exercise; Cardiac rehabilitation; Coronary artery disease.

\section{RESUMO}

Introdução: O treinamento no dinamômetro isocinético é uma alternativa para aumentar a força muscular em pacientes com doença arterial coronariana (DAC). Poucos estudos têm investigado as respostas metabólicas e cardiorrespiratórias do exercício isocinético submáximo em pacientes de um programa de reabilitação cardíaca. Objetivos: Descrever as respostas cardiorrespiratórias em duas intensidades de exercícios isocinéticos. Adicionalmente, comparamos as respostas cardiorrespiratórias do exercício isocinético com os dados de um teste de exercício cardiopulmonar (TECP)

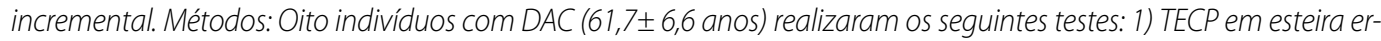
gométrica; 2) Teste de pico de torque (cinco repetições) e resistência à fadiga (20 repetições) de flexão-extensão dejoelho nas velocidades angulares de 120\%/s e 180\%/s; 3) Duas séries de 20 repetições em 30\% a 40\% (baixa intensidade, Bl) e 50\% a 60\% (moderada intensidade, MI) do pico de torque nas velocidades angulares de 120\%/se 180\%/s no dinamômetro isocinético. Durante os exercícios, os indivíduos foram conectados ao analisador de gases expirados com monitoração simultânea do traçado eletrocardiográfico, frequência cardíaca $(F C)$, consumo de oxigênio $\left(V \mathrm{~V}_{2}\right)$, produção de dióxido de carbono e ventilação minuto (VE). Foi calculada a diferença ( $\Delta$ ) entre a medida pico durante os exercícios e os valores basais. Resultados: Tanto a Bl quanto a MI produziram respostas cardiorrespiratórias abaixo do limiar anaeróbico (82,8 $\pm 8,1 \%$ da $F C_{\text {máx }}$ e $74,4 \pm 9,6 \%$ do VO $\mathrm{VP}_{2 \text { icd }}$ comparadas com os dados do TECP $(P<0,01)$. A MI mostrou valores maiores de $\triangle F C(9,8 \pm 5,5$ vs. $6,3 \pm 4,6$ bpm; $P=0,01), \Delta$ duplo produto frequência-pressão $(3.015 \pm 2.286$ vs. $1.957 \pm 1.932 \mathrm{~mm} \mathrm{Hg}$. bpm; $P=0,01)$ e $\Delta V_{E}\left(10,2 \pm 6,2 \mathrm{vs} .6,9 \pm 7 \mathrm{~L} \cdot \mathrm{min}^{-1} ; P=0,03\right)$ quando comparado com a $\mathrm{B} /$ na velocidade angular de $180 \% \mathrm{~s}$. Conclusão: Esses resultados sugerem que este protocolo de exercícios isocinéticos pode ser usado como estratégia para programas de reabilitação cardíaca em pacientes com DAC. Nível de evidência IV; Série de casos.

Descritores: Dinamômetro de força muscular; Consumo de oxigênio; Exercício; Reabilitação cardíaca; Doença da artéria coronariana.

\section{RESUMEN}

Introducción: El entrenamiento en el dinamómetro isocinético es una alternativa para aumentar la fuerza muscular en pacientes con enfermedad arterial coronaria (EAC). Pocos estudios han investigado las respuestas metabólicas y cardiorrespiratorias del ejercicio isocinético submáximo en pacientes de un programa de rehabilitación cardíaca. 
Objetivos: Describir las respuestas cardiorrespiratorias en dos intensidades de ejercicios isocinéticos. Además, comparamos las respuestas cardiorrespiratorias del ejercicio isocinético con los datos de un test de ejercicio cardiopulmonar (TECP) incremental. Métodos: Ocho individuos con EAC (61,7 $\pm 6,6$ años) realizaron los siguientes tests: 1) TECP en cinta ergométrica; 2) Test de pico de torque (cinco repeticiones) y resistencia a la fatiga (20 repeticiones) de flexión-extensión de la rodilla en las velocidades angulares de 120\%/s y 180\%/5; 3) Dos series de 20 repeticiones en 30\% a 40\% (baja intensidad, BI) y 50\% a 60\% (moderada intensidad, MI) del pico de torque en las velocidades angulares de 120\% y 180\%/s en el dinamómetro isocinético. Durante los ejercicios, los individuos fueron conectados al analizador de gases expirados con monitorización simultánea del trazado electrocardiográfico, frecuencia cardiaca ( $F C$ ), consumo de oxígeno (VO2), producción de dióxido de carbono y ventilación minuto (VE). Fue calculada la diferencia ( $\Delta$ ) entre la medida pico durante los ejercicios y los valores basales. Resultados: Tanto BI como MI produjeron respuestas cardiorrespiratorias por debajo del umbral anaeróbico $\left(82,8 \pm 8,1 \%\right.$ de la $F C_{\max }$ y $74,4 \pm 9,6 \%$ del VO2 $2_{\text {pico }}$ ) en comparación con los datos de la TECP $(P<0,01)$. La Ml mostró valores mayores de $\triangle F C(9,8 \pm 5,5$ vs $6,3 \pm 4,61 \mathrm{pm} ; P=0,01), \triangle$ producto frecuencia-presión (3015 \pm 2286 vs. $1957 \pm 1932 \mathrm{mmHg} .1 \mathrm{pm} ; P=0,01)$ y $\Delta V E\left(10,2 \pm 6,2 \mathrm{vs} .6,9 \pm 7 \mathrm{~L} . \mathrm{min}^{-1} ; P=0,03\right)$ en comparación con la Bl en la velocidad angular de 180\%s. Conclusión: Estos resultados sugieren que este protocolo de ejercicios isocinéticos puede ser utilizado como estrategia para programas de rehabilitación cardíaca en pacientes con EAC. Nivel de evidencia IV; Serie de casos.

Descriptores: Dinamómetro de fuerza muscular; Consumo de oxígeno; Ejercicio; Rehabilitación cardiaca; Enfermedad de la arterial coronaria.

\section{INTRODUCTION}

Aerobic and muscle strengthening exercises are widely used in cardiac rehabilitation (CR) programs., ${ }^{1,3}$ Muscle strengthening exercises can control risk factors such as obesity and insulin resistance, improve blood pressure, reduce peripheral vascular resistance, and optimize endothelial function ${ }^{3-5}$ Resistance training promotes improvements in quality of life and functional capacity in patients with cardiac disease. ${ }^{6,7}$ However, there are few studies about cardiovascular, metabolic, and ventilatory responses during strengthening exercises, using an isokinetic dynamometer in patients with coronary artery disease (CAD).

The prescription for strengthening exercises considers the intensity, number of repetitions and sets, weekly volume, and type of muscl contraction. ${ }^{3}$ Depending on the intensity of the training, different muscle and cardiovascular adaptations will occur. ${ }^{4}$ Using the isokinetic dynamometer is an alternative method to perform muscle strengthening protocols. Feiereisen et al. ${ }^{8}$ showed that the measurement of strength gain after a period of training in patients with heart failure is more reliable when assessed using an isokinetic dynamometer compared to the 1-repetition maximum test (1-RM). Although it is an expensive piece of equipment, its use in clinical practice has been increasing yearly. Isokinetic training has been used in athletes, ${ }^{9}$ and in patients with orthopedic ${ }^{10}$ and neurological ${ }^{11}$ problems.

Previous studies focusing on patients with cardiac disease evaluated the cardiovascular responses considering maximum isokinetic exercises. ${ }^{12,13}$ However, few studies have targeted the submaximal responses to isokinetic exercises. ${ }^{14}$ The evaluation of physiological responses with different isokinetic training protocols can safely control the intensity of load used in the prescription for muscular strengthening exercises using the dynamometer.

The anaerobic threshold (AT) can be determined by the cardiopulmonary exercise test (CPET) and used to recommend the appropriate level of training intensity in CR programs. ${ }^{15}$ Different intensities of muscle strengthening exercises may require metabolic responses above or below the AT. There are few studies that investigate the physiological responses to strengthening exercises compared to the responses obtained during an incremental CPET. ${ }^{16}$

The evaluation of acute physiological adaptations to different muscle strengthening protocols is a current topic of interest in the literature.
Our study investigated cardiorespiratory responses during the execution of muscle strengthening exercises at 30-40\% (low intensity, LI) and 50-60\% (moderate intensity, MI) of peak torque at angular speeds of $120 \%$ s and $180 \%$ s on the isokinetic dynamometer, in patients with CAD participating in a CR program.

\section{MATERIALS AND METHODS}

This is a cross-sectional study, initially consisting of 10 individuals with CAD, referred by a doctor to a CR program (Table 1). Five men and three women, aged 53-70 years, classified as low or moderate risk in accordance with the risk stratification of the American Association of Cardiovascular and Pulmonary Rehabilitation, ${ }^{1}$ completed the program. This classification aims to estimate the risk of possible complications during the exercises.

The sample was recruited by accessibility and composed of seven patients post-percutaneous-coronary-angioplasty and one patient post myocardial revascularization. Exclusion criteria were patients at high risk of events according to the classification proposed by the American Association of Cardiovascular and Pulmonary Rehabilitation ${ }^{1}$ and absolute contraindications to performing physical exercise. ${ }^{2}$ This study was approved by the local Institutional Research Ethics Committee and each subject signed a written informed consent ( $n^{\circ}$ 1.231.304/2015).

The subjects visited the lab on four different occasions. Initially, the patients were submitted to a clinical evaluation, performed by a

Table 1. Characteristics of the patients.

\begin{tabular}{c|c}
\hline Anthropometric/demographics data & \\
\hline Sex (M/F) & $5 / 3$ \\
\hline Age (years) & $61.75 \pm 6.65$ \\
\hline Weight (kg) & $79.46 \pm 21.17$ \\
\hline BMl $\left(\mathrm{kg} / \mathrm{m}^{2}\right)$ & $27.97 \pm 7.80$ \\
\hline Ejection fraction (\%) & $52.5 \pm 9$ \\
\hline Main medications & $5(62.5)$ \\
\hline Beta-blockers, $\mathrm{n}(\%)$ & $5(62.5)$ \\
\hline ACE inhibitors or ARB, $\mathrm{n}(\%)$ & $3(37.5)$ \\
\hline Diuretics, $\mathrm{n}(\%)$ & $5(62.5)$ \\
\hline Anticoagulants, $\mathrm{n}(\%)$ &
\end{tabular}

Values are presented in mean and standard deviation. BMI: body mass index; ACE: angiotensin-converting enzyme ARB: angiotensin II receptor blockers. 
cardiologist, followed by CPET, on a treadmill (Imbramed ${ }^{\circledR}$ ATL 10000) with ramp protoco ${ }^{17}$ and expired gas analysis (Ergo software PC Elite, VO2000-MedGraphics ${ }^{\circledR}$ ). The determination of the AT was made by a ventilatory technique, ${ }^{18}$ identifying the lowest points of the ventilatory equivalent for oxygen $\left(\mathrm{VE} / \mathrm{NO}_{2}\right)$ and expired fraction of $\mathrm{O}_{2}$ before starting their elevation. The values presented for the AT and the peak effort were calculated as averages over 40 seconds.

On the second visit, evaluations of peak torque (five repetitions) and fatigue resistance (20 repetitions) were carried out at angular velocities of $120^{\circ} / \mathrm{s}$ and $180^{\circ} / \mathrm{s}^{19,20}$ of the dominant knee, on the isokinetic dynamometer (Biodex ${ }^{\circledR}$ Multi Joint System 3 Pro). The velocities were tested in random order with an interval of five minutes between tests. Initially, blood pressure was checked and warm-up was conducted on the exercise bike without load for five minutes. Individuals became familiar with the dynamometer with active movements of flexion and extension of the knee, in a series of five repetitions at an angular velocity of $300 \%$.

The protocol used was the concentric unilateral mode for the extensor and knee-dominant flexor muscles. During the exercises, the participants were monitored with electrocardiograms of three derivations (CM5, D2M, and V2M) and the expired gases in an open circuit were analyzed (VO 2000-MedGraphics $\left.{ }^{\circledR}\right)$. Oxygen consumption $\left(\mathrm{VO}_{2}\right)$, minute ventilation $\left(V_{E}\right)$, respiratory quotient $(R Q)$, heart rate $(H R)$, and blood pressure (BP) were quantified. ${ }^{13}$ The rate pressure product (RPP) was obtained by multiplying the HR by systolic blood pressure (SBP).

On the third and fourth visits, training sessions at angular velocities of $120 \%$ and $180 \%$ s were conducted. ${ }^{10,11}$ During each visit, four sets of 20 repetitions with rest intervals of three minutes between each set were carried out. LI represents 30-40\% of peak torque and Ml represents 50-60\% of peak torque obtained from isokinetic evaluations. As described above, participants were monitored with electrocardiograms and the expired gases were analyzed. To develop strength at the desired intensity, participants were encouraged through visual feedback on an isokinetic monitor screen with two horizontal lines ${ }^{21}$ There were also verbal stimuli to guide the training intensity. The SBP was measured before and immediately after the execution of the resistance movements. After the end of the session, the patients performed active stretches of the lower limbs. The interval between visits was at least 48 hours. All participants were taking their prescribed medications on the days of the study. The steps of this study are illustrated in Figure 1.

\section{Statistical analysis}

The Shapiro-Wilk test was employed to check the normality of the data distribution. Comparisons between the angular velocities and intensities were conducted by the Student's t-test for dependent samples (parametric data) or the Wilcoxon test (nonparametric data). The one-way analysis of variance was employed to compare the $\mathrm{HR}$ and $\mathrm{VO}_{2}$ between the intensity of the AT and the responses to the isokinetic training, followed by the Tukey post-hoc test. $P$-values $<0.05$ were considered significant.

\section{RESULTS}

Physiological responses to the CPETs are summarized in Table 2. No patient experienced complications during testing. The participants obtained $\mathrm{VO}_{2 \text { peak }}$ of $21.3 \mathrm{~mL} \cdot \mathrm{min}^{-1} \mathrm{~kg}^{-1}$ and $\mathrm{HR}_{\max }$ of $138 \mathrm{bpm}$ on the CPET and the AT intensity was identified at $74.2 \%$ of the $\mathrm{VO}_{2 \text { peak }}$ and $82.2 \%$ of the $H R_{\text {max }}$.

The values of total work $(J)$ were significantly higher at the angular velocity of $120 \% \mathrm{~s}$ when compared to the values obtained at $180 \%$ s $(P=0.01)$. The training workload at $120 \% \mathrm{~s}$ at $\mathrm{LI}$ ranged from 21.2 to 28.1 $\mathrm{N} \cdot \mathrm{m}$ and at $\mathrm{Ml}$ ranged from 35.2 to $42.2 \mathrm{~N} \cdot \mathrm{m}$. At the training at $180^{\circ} / \mathrm{s}$, the workload at LI ranged from 17.5 to $23.3 \mathrm{~N} \cdot \mathrm{m}$ and at Ml ranged from 29.1 to $35 \mathrm{~N} \cdot \mathrm{m}$. (Table 3)

At the velocity of $120 \% / \mathrm{s}$, there was a significant difference in delta variation $(\Delta)$ in $\bigvee_{\mathrm{E}}\left(5.7 \pm 2.0 \mathrm{~L} \cdot \mathrm{min}^{-1} \mathrm{Vs} .9 \pm 1.9 \mathrm{~L} \cdot \mathrm{min}^{-1} ; P=0.03\right)$, indicating greater ventilatory response at MI, from 50 to $60 \%$ of peak torque. (Table 4) At the velocity of $180 \%$ s there was a significant difference in delta variation in HR (6.3 \pm 4.6 bpm vs. $9.8 \pm 5.5$ bpm; $P=0.01)$ and RPP (1957 \pm $1932 \mathrm{mmHg} \cdot \mathrm{bpm}$ vs. $3015 \pm 2286 \mathrm{mmHg} \cdot \mathrm{bpm} ; P=0.01$ ), indicating greater cardiorespiratory response at $\mathrm{MI}$, from 50 to $60 \%$ of peak torque.

In Figure 2A, the \%HR max measured at AT obtained during the CPET was significantly higher when compared with the isokinetic training at $120 \%$ and $180 \%$ s $(P<0.001)$. In Figure $2 \mathrm{~B}$, the $\mathrm{O}_{2 \text { peak }}$ measured at the AT obtained during the CPET was significantly higher when compared with the isokinetic training at $120 \% / \mathrm{s}$ and $180 \%$ s $(P<0.001)$.

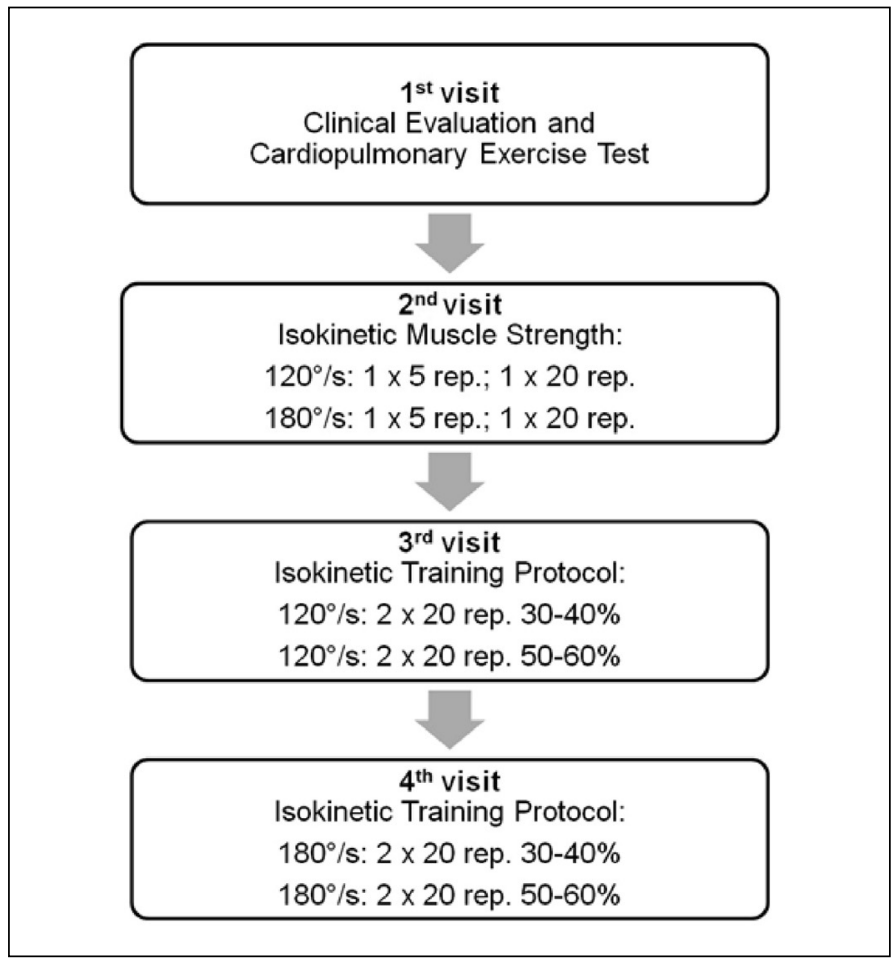

Figure 1. Experimental design. CPET: cardiopulmonary exercise testing; Rep: repetitions.

Table 2. Physiological responses to ramp protocol incremental on treadmill.

\begin{tabular}{c|c}
\hline Cardiopulmonary Exercise Testing & \\
\hline $\mathrm{VO}_{2 \text { peak }}\left(\mathrm{mL} \cdot \mathrm{min}^{-1} \cdot \mathrm{kg}^{-1}\right)$ & $21.39 \pm 6.93$ \\
\hline $\mathrm{VO}_{2 A \mathrm{AT}}\left(\mathrm{mL} \cdot \mathrm{min}^{-1} \cdot \mathrm{kg}^{-1}\right)$ & $15.87 \pm 5.74$ \\
\hline$H R_{\max }(\mathrm{bpm})$ & $138.8 \pm 16.5$ \\
\hline $\mathrm{HR} \mathrm{R}_{\mathrm{AT}}(\mathrm{bpm})$ & $114.25 \pm 11.42$ \\
\hline $\mathrm{SBP}(\mathrm{mmHg})$ & $152.5 \pm 13.8$ \\
\hline $\mathrm{RPP}\left(\mathrm{mmHg} \cdot \mathrm{bpm}^{-1}\right)$ & $21233 \pm 3536$ \\
\hline $\mathrm{RQ}$ & $1.02 \pm 0.11$ \\
\hline $\mathrm{V}_{\mathrm{E}}\left(\mathrm{L} \cdot \mathrm{min}^{-1}\right)$ & $40.8 \pm 9.1$
\end{tabular}

Values are presented in mean and standard deviation. $\mathrm{VO}_{2 \text { peak: }}$ Oxygen consumption at peak stress; $\mathrm{VO}_{2 \mathrm{AT}}$ : Oxygen consumption in anaerobic threshold; $\mathrm{HR}_{\text {max }}$ : maximum heart rate; $\mathrm{HR}_{\mathrm{AT}}$ : heart rate in anaerobic threshold; $\mathrm{SBP}$ : systolic blood pressure; RPP: rate pressure product; $R Q$ : respiratory quotient; $\mathrm{V}_{\mathrm{E}}$ : minute ventilation.

Table 3. Isokinetic data and cardiovascular, metabolic and ventilatory responses during the assessment protocol of the knee extensor muscles at $120 \% \mathrm{~s}$ and $180 \% \mathrm{~s}$.

\begin{tabular}{c|c|c|c|c}
\hline & Repetitions & $\mathbf{1 2 0} / \mathbf{s}$ & $\mathbf{1 8 0} / \mathbf{s}$ & $\mathbf{P}$ \\
\hline Peak Torque $(\mathrm{N} \cdot \mathrm{m})$ & 5 & $70.4 \pm 37.4$ & $58.3 \pm 18.9$ & 0.30 \\
\hline Fatigue $(\%)$ & 20 & $28.2 \pm 7.4$ & $24.2 \pm 10.4$ & 0.49 \\
\hline Total work $(\mathrm{J})$ & 20 & $1500 \pm 608$ & $1299 \pm 730$ & $0.01^{*}$ \\
\hline $\mathrm{HR}(\mathrm{bpm})$ & 20 & $97.1 \pm 15$ & $94.9 \pm 18.2$ & 0.34 \\
\hline $\mathrm{SBP}(\mathrm{mmHg})$ & 20 & $151.3 \pm 25$ & $138.8 \pm 30$ & 0.31 \\
\hline $\mathrm{RPP}\left(\mathrm{mmHg} \cdot \mathrm{bpm}^{-1}\right)$ & 20 & $14651 \pm 2964$ & $13063 \pm 3335$ & 0.24 \\
\hline $\mathrm{VO}_{2}\left(\mathrm{~mL} \cdot \mathrm{kg}^{-1} \cdot \mathrm{min}^{-1}\right)$ & 20 & $10.3 \pm 2.1$ & $9.1 \pm 1.4$ & 0.37 \\
\hline $\mathrm{V}_{\mathrm{E}}\left(\mathrm{L} \cdot \mathrm{min}^{-1}\right)$ & 20 & $24.6 \pm 6.7$ & $23.8 \pm 5.8$ & 0.91 \\
\hline
\end{tabular}

Values are presented in mean and standard deviation. HR: heart rate; SBP: systolic blood pressure; RPP: rate pressure product; $\mathrm{VO}_{2}$ : oxygen consumption; $\mathrm{V}_{\mathrm{E}}$ : minute ventilation. ${ }^{*} P<0.05$ when compared to the angular velocity of $120 \%$ 
Table 4. Delta variation in cardiovascular, metabolic and ventilatory responses during knee extensor muscles training at velocities of $120 \% \mathrm{~s}$ and $180 \% \mathrm{~s}$ at two intensities, 30-40\% (LI) and 50-60\% (MI) of peak torque.

\begin{tabular}{c|c|c|c|c}
\hline & \multicolumn{2}{|c|}{$120 \% / \mathrm{s}$ Training } & \multicolumn{2}{c}{$180 \%$ Training } \\
\hline Variables & $30-40 \%$ & $50-60 \%$ & $30-40 \%$ & $50-60 \%$ \\
\hline$\Delta \mathrm{HR}(\mathrm{bpm})$ & $7.8 \pm 6.6$ & $12.2 \pm 9.2$ & $6.3 \pm 4.6$ & $9.8 \pm 5.5^{*}$ \\
\hline$\Delta \mathrm{SBP}(\mathrm{mmHg})$ & $8.7 \pm 15.1$ & $13.7 \pm 11.8$ & $15 \pm 19.2$ & $20.6 \pm 22.7$ \\
\hline$\Delta \mathrm{RPP}(\mathrm{mmHg} \cdot \mathrm{bpm})$ & $1710 \pm 1524$ & $2803 \pm 1772$ & $1957 \pm 1932$ & $3015 \pm 2286^{*}$ \\
\hline$\Delta \mathrm{VO}_{2}\left(\mathrm{~mL} \cdot \mathrm{kg}^{-1} \cdot \mathrm{min}^{-1}\right)$ & $4.0 \pm 2.5$ & $4.7 \pm 1.6$ & $3.7 \pm 2.4$ & $4.6 \pm 2$ \\
\hline$\Delta \mathrm{V}_{\mathrm{E}}\left(\mathrm{L} \cdot \mathrm{min}^{-1}\right)$ & $5.7 \pm 2.0$ & $9 \pm 1.9^{*}$ & $6.9 \pm 7$ & $10.2 \pm 6.2$ \\
\hline
\end{tabular}

Values are presented in mean and standard deviation Delta variation $(\Delta)$ represents the difference of the measured values at the end of 20 repetitions minus the rest values. ${ }^{*} P<0.05$ when compared to the intensity of $30-40 \%$. HR heart rate; $\mathrm{SBP}$ : systolic blood pressure; $\mathrm{RPP}$ : rate pressure product; $\mathrm{VO}_{2}$ : oxygen consumption; $\mathrm{V}_{\mathrm{E}}$ : minute ventilation.

\section{(}
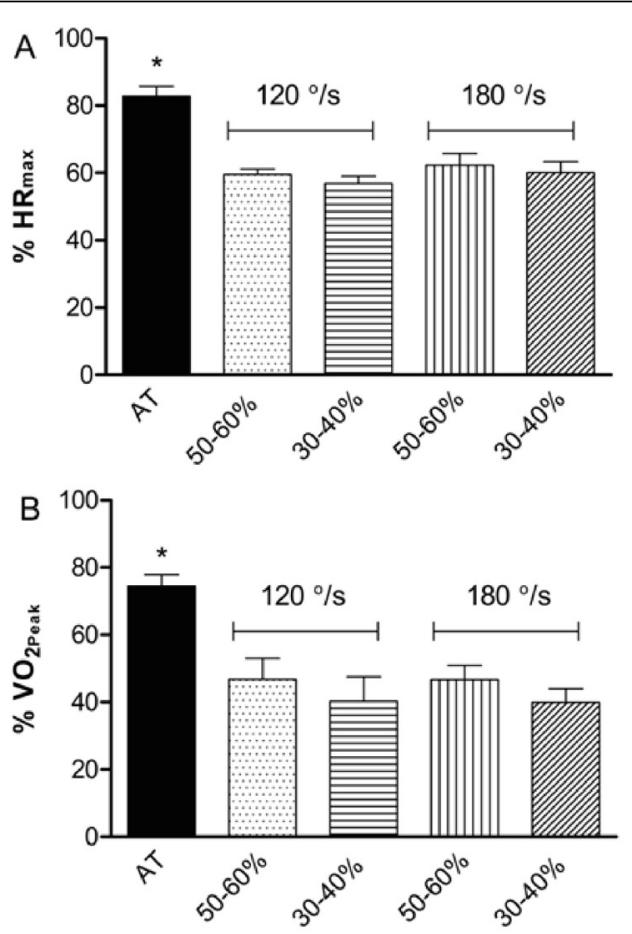

AT: anaerobic threshold; HRmax: maximum heart rate; ${ }^{*} P<0.05$ when compared to the isokinetic exercises.

Figure 2. Percentage of $\mathrm{HRmax}(\mathrm{A})$ and percentage of $\mathrm{VO}_{2}$ peak (B) obtained during the CPET at AT intensity and during isokinetic muscle training (20 repetitions of knee flexion and extension) at $120 \%$ s and $180 \%$ s in two training situations with load of $50-60 \%$ and $30-40 \%$ of peak torque

\section{DISCUSSION}

The present study investigated the cardiorespiratory responses during 20 repetitions on an isokinetic dynamometer at two intensities at $120 \%$ s and $180 \%$ s angular velocities in patients with CAD. The main finding was that short periods of repetition at fast speeds are safe and well tolerated by patients with CAD. During isokinetic training at $120 \% \mathrm{~s}$ and $180 \%$ s, at both studied intensities (LI and MI), cardiorespiratory overloads were below the AT measured during the CPET.

Another important result was the evaluation of the metabolic and chronotropic responses from isokinetic exercise in relation to the $\% \mathrm{VO}_{2 \text { peak }}$ and $\% \mathrm{HR}_{\max }$ obtained during the CPET. Patients performed exercises on the isokinetic dynamometer at an average of $53 \%$ of $\mathrm{VO}_{2 \text { peak }}$ and $70 \%$ of $\mathrm{HR}_{\max }$. These results show that the isokinetic exercises occurred at an intensity below the AT, suggesting that the isokinetic muscle strengthening protocol used in this study can be safely carried out in CR programs. Our results are in agreement with a study where the resistance exercises promoted smaller hemodynamic responses when compared to a walk on the treadmill at $80 \%$ of $\mathrm{VO}_{2 \text { peak }}$ intensity in patients with heart failure. ${ }^{22}$
No changes were observed in the ischemic ST-segment depression, ventricular arrhythmias, or angina during the training protocol. However, Caruso et al. ${ }^{16}$ reported increased ventricular extrasystoles during the leg press exercise at an intensity of 60\% 1-RM in patients with CAD. Additionally, they showed that the hemodynamic responses to leg presses were similar to the ones observed in the peak effort during the CPET, ${ }^{16}$ in contrast with the results of the present study. It is possible that the mode and duration of exercise (two minutes) explain these differences.

Isokinetic strengthening protocols in patients who are postoperative myocardial revascularization were considered safe when they used loads of 20 to $30 \%$ of the peak torque. ${ }^{14}$ Our results extend the safe use of the isokinetic dynamometer at the intensity of $50-60 \%$ of peak torque, when held for short periods of duration, with 20 repetitions at $120 \%$ or $180 \%$ s. However, another study ${ }^{23}$ showed a significant increase in SBP to $205 \mathrm{mmHg}$ when the isokinetic exercises were performed for periods of two minutes at $50 \%$ of peak torque, at the velocity of $90 \% \mathrm{~s} \mathrm{in}$ healthy seniors. Additionally, the authors reported greater cardiovascular responses in concentric exercises when compared to eccentric exercises in young and old people. ${ }^{23}$

The recommendation for isokinetic resistance training must consider the volume, intensity, and type of exercise performed, because they directly influence the hemodynamic and metabolic responses. ${ }^{3}$ Additionally, the recovery period for $\mathrm{HR}$ and $\mathrm{BP}$ between sets should be 60 seconds for the elderly or patients with heart failure ${ }^{13}$. The investigation of responses to submaximal exercise on the isokinetic dynamometer can safely guide the resistance training, avoiding undesirable levels of SBP in CR. ${ }^{12,13}$

In patients with heart failure, Degache et al. ${ }^{13}$ reported higher cardiovascular responses at the velocity of $240 \%$ s and $180 \%$ s when compared to the velocity of $60 \%$, suggesting that the HR and the RPP increase because of the angular velocity and the exercise intensity. Our results confirmed major responses of the RPP at $180^{\circ}$ s. The pressure overloads during the strengthening exercises' execution deserve more attention by the prescribers. Therefore, the measurement of RPP has been recommended because it is an indirect indicator of oxygen uptake by myocardium., 37

In subjects with intermittent claudication, the HR and the RPP were higher in knee flexion/extension exercises compared to the plantar flexion /dorsiflexion exercise. ${ }^{11}$ The authors suggest that the greater muscle mass involved in knee flexion/extension exercise may be related to increased hemodynamic responses. ${ }^{11}$ In a study with 28 patients with heart disease who were taking Beta-blockers, performing isokinetic exercise, a significant increase in HR was observed at an angular velocity of $90 \%$, but below $70 \%$ of $\mathrm{HR}_{\max }$ obtained in an exercise stress test, corroborating our results. ${ }^{24}$ Our results showed an average chronotropic response of six to 12 bpm, with an average time to run the 20 repetitions of 60 seconds, with $62 \%$ of the patients in the sample taking Beta-blockers. This initial increase of $\mathrm{HR}$ suggests a vagal inhibition of the sinoatrial node in the first 10 seconds of the exercise, as reported by other authors. ${ }^{11,23}$

In our study, we found mean values for the peak torque of knee extensors of $70.4 \mathrm{~N} \cdot \mathrm{m}$ and $58.3 \mathrm{~N} \cdot \mathrm{m}$ at angular velocities of $120 \% \mathrm{~s}$ and $180 \%$, respectively. Ghroubi et al. ${ }^{14}$ reported peak torques of $89 \mathrm{~N} \cdot \mathrm{m}$ at an angular velocity of $150 \%$ and $82 \mathrm{~N} \cdot \mathrm{m}$ at $180 \% \mathrm{~s}$ in patients who are postoperative for myocardial revascularization. Other authors reported peak torques of $91 \mathrm{~N} \cdot \mathrm{m}$ and $76 \mathrm{~N} \cdot \mathrm{m}$ at velocities of $120 \% \mathrm{~s}$ and $180 \%$, respectively, in patients with heart failure. ${ }^{20}$ In addition, we observed higher values of total work $(\mathrm{J})$ at a velocity of $120 \% \mathrm{~s}$, although without significant differences in percentage of fatigue (Table 2). The total work represents the torque product by angular displacement and reflects the energy developed during muscle activity. ${ }^{25}$ It is believed that at a velocity of $120 \%$ s there was greater recruitment of motor units, in much of the range of motion, with a consequent increase in bioenergetics demand by the muscles. ${ }^{26}$ 
The exercises at $120^{\circ} / \mathrm{s}$ required superior responses of $\mathrm{VO}_{2}(P=0.37)$, SBP $(P=0.31)$, and RPP $(P=0.24)$, although without statistically significant differences when compared to $180^{\circ} / \mathrm{s}$. These results may partially explain the higher output of work found at the lowest velocity.

Isokinetic training at high angular velocity of $240 \%$ s has been studied in the elderly and showed increased expression of isoforms of myosin heavy chain and superior functional improvements to the training at low velocity of $75^{\circ} / \mathrm{s}^{27}$. Currently, it is suggested that adaptations in skeletal muscles triggered by resistance training are specific for each angular velocity. ${ }^{27}$ With aging, occurs loss of fast-twitch muscle fibers (type II) and consequent reduction of peak torque measured at a velocity of $180^{\circ} / \mathrm{s} \cdot{ }^{28} \mathrm{An}$ isokinetic training protocol at an angular velocity of $180 \%$ increased the peak torque of knee extensors $40 \%$ in patients with cardiac disease. ${ }^{14}$ In this context, resistance training is an important complement to aerobic exercise to improve muscular strength, tolerance to the efforts, and quality of life. ${ }^{3,5,7}$

Some limitations must be considered in this study. The small number of participants and the inclusion of women and men must be taken into consideration in the interpretation of our results, although other studies have used seven to nine individuals and evaluated the same variables. 29,30 Our results refer to an acute effect of isokinetic strengthening exercise. Future studies can assess whether the proposed protocol promotes muscle strength gain.

\section{CONCLUSION}

The hemodynamic and metabolic responses to isokinetic exercises occurred below the AT and they can be safely performed in CR programs. There were no cardiovascular complications or musculoskeletal injuries during the isokinetic exercises. We suggest this isokinetic protocol and the angular velocities used in resistance training be prescribed for patients with CAD in CR.

All authors declare no potential conflict of interest related to this article

AUTHORS' CONTRIBUTIONS: Each author made significant individual contributions to this manuscript. AER, SB, TCM, and VCF: were responsible for data collection, data analysis and interpretation, and the writing of the manuscript; GLP, JBCR and TGH: revised the manuscript and contributed to the intellectual concept of the study; LC: designed the study and supervised the data collection, analysis, and contributed with the writing of the manuscript. All authors read and approved the final manuscript.

\section{REFERENCES}

1. Williams MA, Balady GJ, Carlson JJ. Comoss P, Humphrey, Lounsbury PF. AACVPR. Guidelines for Cardiac Rehabilitation and Secondary Prevention Programs. $4^{\text {th }}$ ed. Champaign, IL: Human Kinetics Publishers, 2004.

2. Herdy AH, Lópes-Jiménez F, Terzic C, Milani M, Stein R, Carvalho T, et al. Diretriz Sul-Americana de Prevenção e Reabilitação Cardiovascular. Arq Bras Cardiol. 2014;103(2 Supl.1):1-31.

3. Williams MA, Haskell WL, Ades PA, Amsterdam EA, Bittner V, Franklin BA, et al. Resistance exercise in individuals with and without cardiovascular disease: 2007 update: A scientific statement from the American Heart Association Council on Clinical Cardiology and Council on Nutrition, Physical Activity, and Metabolism. Circulation. 2007:116(5):572-84

4. Umpierre D, Stein R. Efeitos hemodinâmicos e vasculares do treinamento resistido: implicações na doença cardiovascular. Arq Bras Cardiol. 2007;89(4):256-62.

5. Westcott WL. Resistance training is medicine: effects of strength training on health. Curr Sports Med Rep. 2012;11(4):209-16.

6. Giuliano C, Karahalios A, Neil C, Allen J, Levinger I. The effects of resistance training on muscle strength, quality of life and aerobic capacity in patients with chronic heart failure - A meta-analysis. Int J Cardiol. 2017; 227:413-23.

7. Calegari L, Barroso BF, Bratz J, Romano S, Figueiredo GF, Ceccon M, et al. Efeitos do treinamento aeróbico e do fortalecimento em pacientes com insuficiência cardíaca. Rev Bras Med Esporte. 2017; 23(2):123-7.

8. Feiereisen $P$, Vaillant $M$, Eischen $D$, Delagardelle $C$. Isokinetic versus One-repetition maximum strength assessment in chronic heart failure. Med Sci Sports Exerc. 2010;42(12):2156-63.

9. Golik-Peric D, Drapsin M, Obradovic B, Drid P. Short-term isokinetic training versus isotonic training: effects on asymmetry in strength of thigh muscles. J Hum Kinet. 2011;30:29-35.

10. Santos HH, Sousa CO, Barela JA, Barela AM, Salvini TF. Effects of isokinetic eccentric training on knee extensor and flexor torque and on gait of individuals with long term $A C L$ reconstruction: $A$ controlled clinical trial. Motriz Rev Educ Fis. 2014;20(4):431-41.

11. Büyükvural Şen S, Özbudak Demir S, EkizT, Özgirgin N. Effects of the bilateral isokinetic strengthening training on functional parameters, gait, and the quality of life in patients with stroke. Int J Clin Exp Med. 2015;8(9):16871-9.

12. Câmara LC, Ritti-Dias RM, Forjaz CL, Greve JM, Santarém JM, Jacob-Filho W, et al. Respostas cardiovasculares durante avaliação muscular isocinética em claudicantes. Arq Bras Cardiol. 2010;95(5):571-6.

13. Degache F, Roche F, Bernard P, Calmels P. Cardiovascular responses during isokinetic knee extension testing in chronic heart failure patients. Isokinet Exerc Sci. 2009;17(2):63-7.

14. Ghroubi S, Elleuch W, Abid L, Abdenadher M, Kammoun S, Elleuch MH. Effects of a low-intensity dynamicresistance training protocol using an isokinetic dynamometer on muscular strength and aerobic capacity after coronary artery bypass grafting. Ann Phys Rehabil Med. 2013;56(2):85-101.

15. Pereira DA, Vieira DS, Samora GA, Lopes FL, Alencar MC, Lage SM, et al. Reproducibility of the determination of anaerobic threshold in patients with heart failure. Arq Bras Cardiol. 2010;94(6):771-8.
16. Caruso FR, Junior JC, Mendes RG, Sperling MP, Arakelian VM, Bassi D, et al. Hemodynamic and metabolic response during dynamic and resistance exercise in different intensities: a cross-sectiona study on implications of intensity on safety and symptoms in patients with coronary disease. Am J Cardiovasc Dis. 2016;6(2):36-45.

17. Sociedade Brasileira de Cardiologia. III Guidelines of Sociedade Brasileira de Cardiologia on the exercise test. Arq Bras Cardiol. 2010;95(5 Suppl 1):1-26.

18. Neder JA, Nery LE. Fisiologia clínica do exercício: teoria e prática. 1. ed. São Paulo: Artmed; 2003.

19. Marzorati M, Perini R, Milesi S, Veicsteinas A. Metabolic and cardiorespiratory responses to maximal intermittent knee isokinetic exercise in young healthy humans. Eur J Appl Physiol. 2000;81 (4):275-80.

20. Toth MJ, Miller MS, VanBuren P, Bedrin NG, LeWinter MM, Ades PA, et al. Resistance training alters skeletal muscle structure and function in human heart failure: effects at the tissue, cellular and molecular levels. J Physiol. 2012;590(5):1243-59.

21. lellamo F, Legramante JM, Raimondi G, Castrucci F, Damiani C, Foti C, et al. Effects of isokinetic, isotonic and isometric submaximal exercise on heart rate and blood pressure. Eur J Appl Physiol. 1997;75(2):89-96.

22. Levinger I, Bronks R, Cody DV, Linton I, Davie A. The physiological responses of chronic heart failure patients to maximal strength test and a balke incremental test. J Sports Sci Med. 2004;3(YISI 1):1-7.

23. Overend TJ,Versteegh TH, Thompson E, Birmingham TB, Vandervoort AA. Cardiovascular stress associated with concentric and eccentric isokinetic exercise in young and older adults. J Gerontol A Biol Sci Med Sci. 2000;55(4):B177-82.

24. Kraemer EC. Resposta da frequência cardíaca de cardiopatas beta-bloqueados durante teste de força isocinético para grupo muscular da coxa. Dissertação [Mestrado em Ciências do Desporto]. Vila Real. Universidade de Trás-Os-Montes e Alto Douro; 2013.

25. Ferreira AP, Gomes SA, Ferreira CE, Arruda M, França NM. Avaliação do desempenho isocinético da musculatura extensora e flexora do joelho de atletas de futsal em membro dominante e não dominante. Rev Bras Cienc Esporte. 2010;32(1):229-43.

26. Thorstensson A, Grimby G, Karlsson J. Force-velocity relations and fiber composition in human knee extensor muscles. J Appl Physiol. 1976;40(1):12-6.

27. Englund DA, Sharp RL, Selsby JT, Ganesan SS, Franke WD. Resistance training performed at distinct angular velocities elicits velocity-specific alterations in muscle strength and mobility status in older adults. Exp Gerontol. 2017 22;91:51-6.

28. Jenkins ND, Housh TJ, Palmer TB, Cochrane KC, Bergstrom HC, Johnson GO, et al. Relative difference in strength and power from slow to fast isokinetic velocities may reflect dynapenia. Muscle Nerve. 2015;52(1):120-30.

29. Arimoto M, Kijima A, Muramatsu S. Cardiorespiratory response to dynamic and static leg press exercise in humans. J Physiol Anthropol Appl Human Sci. 2005;24(4):277-83.

30. Velloso M, Stella SG, Cendon S, Silva AC, Jardim JR. Metabolic and ventilatory parameters of four activities of daily living accomplished with arms in COPD patients. Chest. 2003;123(4):1047-53. 